\title{
The descriptive review, from recurrent respiratory papillomatosis of the disease, an enigmatic
}

\section{A revisão descritiva da papilomatose respiratória recorrente da doença, um enigmático}

\author{
Aremu Shuaib Kayode'. \\ 1) DR. Consultant ENT. \\ Mailing Address: Aremu Shuaib Kayode - p.o.box 685, ilorin - UITH, ILORIN - shuaib.aremu@ gmail.com \\ Article received in May 20, 2010. Article approved in September 4, 2010.
}

\section{RESUMO}

Introdução: A papilomatose respiratória recorrente (PRR), que é causado pelo papilomavírus humano tipos 6 e 11, é a neoplasia benigna mais comum da laringe entre as crianças ea segunda causa mais frequente de rouquidão na infância. É uma doença enigmática que pode ser devastadora para aqueles a quem ela afeta. É muito mal compreendido, e investigação continua na ativa assunto.

Objetivo: Esta revisão teve por objectivo proporcionar uma visão global e uma atualização do que é conhecido sobre RRP e que está à frente de interms therapies. This cirúrgica e adjuvante foi realizada através de pesquisa das bases de dados PubMed, MEDLINE, Index cumulativa de Enfermagem e Saúde Allied Literatura e Cochrane biblioteca electrónica procurou usar os cabeçalhos de assunto "papilomatose respiratória recorrente", "papilomatose laríngea juvenil", "papilomatose respiratória", "obstrução laríngea pediátrica" e "gestão das vias aéreas". Os resultados obtidos foram analisados de relevância para o tema.

Discussão: $\mathrm{O}$ papilomavírus humano (HPV) é um pequeno vírus de DNA que contêm. A papilomatose respiratória recorrente pode afetar pessoas de qualquer idade, com o paciente mais jovem identificado em um dia de idade eo mais velho de 84 anos. A apresentação mais comum é o sustentáculo da PRR é hoarseness. The de terapia tem sido repetida debulking. O objetivo é erradicar a doença, sem danificar as estruturas normais. Nenhum única modalidade tem mostrado ser eficaz na erradicação da PRR.

Conclusão: Papilomatose respiratória recorrente é uma doença frustrante caprichoso com o potencial para consequências mórbidas por causa de seu envolvimento das vias aéreas eo risco de degeneração maligna.

Palavras-chave: Herpesvirus Saimiriíneo 2.

\section{SUMMARY}

Introduction: The recurrent respiratory papillomatosis (RRP), which is caused by the human papilomavirus type 6 and 11 , is the most common benign neoplasm in the larynx among infants and the second more frequent cause of the hoarseness in childhood. Is a enigmatic disease that can be devastating for those whom are affected. Is way misunderstood, and the investigation is still on matter.

Objective: This review had as objective provide a global vision and an update of what is recognized about the RRP and that is ahead of interns therapies. This surgical and adjuvant was performed through the research of database PubMed, MEDLINE, Cumulative index to nursing and health, Allied Literature and Cochrane. Eletronic library sought to use the headers of the subject "Recurrent Respiratory Papillomatosis", "Juvenile Laryngeal Papillomatosis", "Respiratory Papillomatosis", "Pediatric Laryngeal Obstruction" and "Airway Management". The obtained results were analyzed of relevance for the theme.

Discussion: The human papillomavirus (HPV) is a little DNA virus that contain. The recurrent respiratory papillomatosis can affect people of any age, with the younger patient identified in a day of age and the oldest with 84 years. The most common presentation is the supporter of the RRP, it is the hoarseness. The therapy has been repetitive and debulking. The objective is to erradicate the disease, without damaging the normal structures. None modality has proven effective in the eradication of RRP.

Conclusion: Recurrent Respiratory Papillomatosis is a frustrating disease, capricious with the potential of the morbid consequences by the cause of involvement of the airway and the risks of malignant degeneration.

Keywords: Herpesvirus Saimirineo 2. 


\section{INTRODUCTION}

The scientific knowledge of RRP has been a slowly progressive one. It dated back to 1923 when Ullmann verified its infectious etiology by injecting homogenized papillomata from a child's larynx into his own forearm and observing the development of papillomata there (1). Subsequently in 1956, a pediatrician made an association between maternal condylomata and the risk of childhood infection (2). In 1973 an intranuclear icosahedral virus was identified in lesions by electron microscopy (3), and in 1980 human papillomavirus (HPV) DNA was identified in papillomata (4). Although, initially called juvenile laryngeal papillomatosis, the disease has been increasingly recognized in adults and not only limited to the larynx. Therefore, it generally goes by the name recurrent respiratory Papillomatosis. It has been described to have a juvenile or aggressive form and an adult or less aggressive form. However, the aggressive form may occur in an adult and vice versa. There has been an association between maternal cervical HPV infection and the incidence of RRP (5). Surgical debulking was advanced with the use of the $\mathrm{CO}_{2}$ laser and suspension microlaryngoscopy in 1972 (6) which remains a gold standard. Current lines of treatment include the use of drugs to slow the disease progression. It should be noted that frequent biopsies of patients and close follow-up are needed to detect squamous metaplasia, dysplasia, or conversion to SCC. Such a progression to SCC may occur but is rare $(7,8)$.

The objective of this review is to provide us with an overview and an update of what is known about RRP in terms of pathological science,epidemiology, clinical presentation, diagnosis and treatment. It will also inform us what lies ahead interms of surgical and adjuvant therapies.

\section{METHOD}

Databases for PubMed, MEDLINE, Cumulative Index of Nursing and Allied Health Literature and Cochrane library were electronically searched using the subject headings Recurrent Respiratory Papillomatosis, laryngeal papillomatosis, juvenile respiratory papillomatosis, pediatric laryngeal obstruction and airway management. The results generated were reviewed for relevance to the topic.

\section{Pathological Science}

Human papillomavirus (HPV) is a small, DNAcontaining, nonenveloped icosahedral (20-sided) capsid virus with a double-stranded circular DNA that is 7900 base pairs (bp) long.
Belongs to the Papovavirus family. "Papova" is an acronym for the three types of viruses in the family papillomavirus, polyomavirus, and simian vacuolating virus. There are only three papovaviruses pathogenic to humans: $\mathrm{HPV}$, and JC and BK viruses which are polyoma viruses (JC virus has been implicated in progressive multifocal leukencephalopathy and BK virus has been isolated from urine of kidney transplant recipients).

90 subtypes of HPV are known (9), but only a few subtypes commonly cause RRP. These are RRP 6 and 11 . They also cause condyloma acuminata (genital warts). To be a subtype, a strain has to exhibit less than 90\% homology with other subtypes, and certain subtypes which behave in a similar fashion clinically have been found to have similar homology (10). These include 6 and 11, 16 and 18, and 31,33, and 35 . Today, with the use of viral probes, HPV DNA has been identified in virtually every papilloma lesion studied.The original strains identified were labeled $6 \mathrm{C}-6 \mathrm{~F}$ but $6 \mathrm{C}$ was later determined to be different enough to be classified as its own strain, HPV 11.16 and 18 have been implicated as causative in cancer, particularly of the uterine cervix.

E6 and E7 are nuclear transforming proteins sometimes made by the virus which have been implicated in malignant transformation. They are thought to play a role in molecular biological typing of individual lesions.

\section{Epidemiology}

Recurrent respiratory papillomatosis may affect people of any age, with the youngest patient identified at 1 day of age and the oldest at 84 years (11). True incidence and prevalence of RRP are uncertain. In a Danish subpopulation incorporating $50 \%$ of the population of that country, the incidence of laryngeal Papillomatosis was 3.84 cases per 100,000.The rate among children was 3.62 per 100,000 , whereas adult-onset cases occurred at a rate of 3.94 per 100,000 . These data are comparable with those found in a recent U.S. survey, which estimated an incidence in the pediatric population of 4.3 per 100,000 children and 1.8 per 100,000 adults.

This translates into approximately 2300 new pediatric cases per year in the United States (12).

It has been estimated to affect 15,000 total people in the United States, 6,000 of them being children. There are 2300 new cases among children and 3600 new cases among adults diagnosed each year, with an incidence of 4.3 and 1.8 per 100,000, respectively. Diagnosis and treatment cost \$151 million annually (13). 
Initially believed to be a disease of children it is now known to have a bimodal distribution in ages with the first peak in children, majority presenting by age five. Approximately $25 \%$ will present by age one, $75 \%$ by age five and the remainder of juvenile onset RRP by puberty (14). Childhood-onset RRP (arbitrarily defined as patients diagnosed at less than $12 \mathrm{y}$ of age) is most often diagnosed between 2 and 4 years of age.Adult RRP peaks between the ages of 20 and 40 and has a slight male predilection; distribution among boys and girls is approximately equal and there are noapparent differences in surgical frequencies by gender or ethnicity (14). Boys and girls are equally affected. Retrospective and recent prospective studies have confirmed that HPV may be passed by vertical transmission from mother to child. In addition; Kashima et al. (15) found that patients with childhood-onset RRP were more likely to be firstborn and vaginally delivered than were control patients of similarage. There is a predilection for the firstborn child. In fact, the triad of the firstborn, vaginally-delivered infant of a teenage mother has been recognized as a risk factor for the disease. RRP is rare in nontwin sibling pairs. In the past it was thought that children with RRP would spontaneously remit at the onset of puberty due to hormonal changes, but this has not been found to be true.

Transmission is thought to be multi-factorial, but in children the most common risk factor has been vertical transmission during birth from maternal HPV infection. Most studies indicate that juvenile-onset RRP occurs during exposure from a mother with genital HPV infection during normal vaginal delivery (16). Cesarean section may provide protection from HPV, and only 1 of 109 patients born by Cesarean section developed RRP in one study (17).

Because many babies are exposed during childbirth and only a few develop RRP, it has been suggested that genetically encoded host susceptibility may play a role in disease progression (18).

Other postulated routes include hematogenous spread and ascending transplacental inoculation. Mothers of affected children can recall by history active or prior HPV infection $50 \%$ of the time. However, the understanding of the cause and effect is nebulous at best. It has been estimated that 10-25\% of women of childbearing age have been shown to have evidence of latent or active HPV in cervical swabs, and HPV DNA has been found in one-third to one-half of aero-digestive tract swabs of children born to affected mothers. However, the majority of these children do not develop disease. The risk of developing disease is not precisely known but has been estimated at 1 in 400 (10). There is not a consensus regarding the role of cesarean section for prevention of disease in mothers with
HPV infection. Ultimately, the decision is one between a woman and her obstetrician, but the literature generally does not endorse prophylactic cesarean sections in the absence of other indications (19). A landmark study by Shah evaluated 109 children with RRP and found only one to have been born by cesarean section, much lower than would be predicted (20).

\section{Clinical Presentation and Diagnosis}

The most common presentation is of RRP is hoarseness. Young children may also present with weak cry, chronic cough, or stridor. Adults may present with other symptoms such as globus. Persistent or progressive stridor and dysphonia, with the possible development of respiratory distress, are the most consistent signs and symptoms of RRP in children. In the absence of severe respiratory distress, a careful history should be obtained. Information regarding the time of onset of symptoms, possible airway trauma including a history of previous intubation, and characteristics of the cry are, obviously, important. Hoarseness, although a common and often benign clinical complaint in young children, always indicates some abnormality of structure or function. Because of the precision of laryngeal mechanics, hoarseness may result from a remarkably small lesion and thus be an early sign in the course of a disease process. On the other hand, if the lesion's origin is remote from the vocal cords, hoarseness may present as a late sign. The quality of the voice change may give only limited clues to its etiology, while other characteristics such as age of onset, rate of progression,associated infection, history of trauma or surgery, and the presence of respiratory or cardiac distress may be of much greater significance. A low-pitched, coarse, fluttering voice suggests a subglottic lesion, whereas a highpitched, cracking voice; aphonia; or a breathy voice suggests a glottic lesion. Associated high-pitched stridor also suggests a glottic or subglottic lesion. Although stridor that has been present since birth is more often associated with laryngomalacia, subglottic stenosis, vocal cord paralysis, or a vascular ring, it should be realized that neonates can also present with papillomatosis. Associated symptoms such as feeding difficulties, allergic symptoms, vocal abuse, and the presence of hereditary congenital anomalies may help distinguish RRP from alternative diagnoses, including vocal fold nodules, vocal fold paralysis, subglottic cysts, subglottic hemangioma, and subglottic stenosis.

In the absence of any history suggesting these lesions, review of the peri-natal period may reveal a history of maternal or paternal condylomata.

The diagnosis is usually made upon the visualization of warty excrescences and confirmed by biopsy in the 


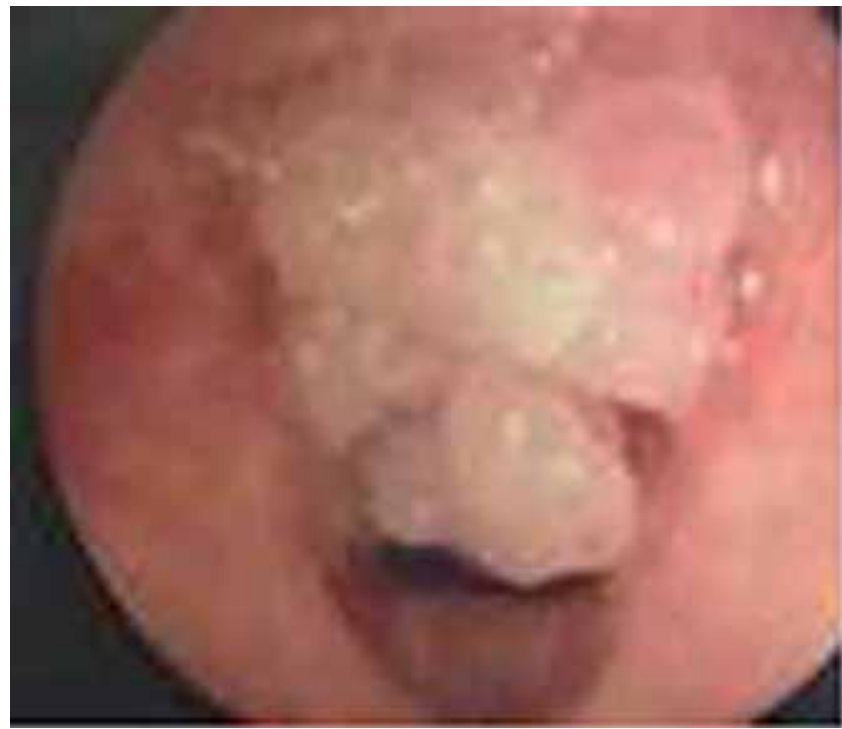

Figure 1. Pappillomatous lesion within the larynx.

operating room. Histologically there is an epithelial projection with a fibrovascular core, and there is associated parakeratosis, koilocytosis, and acanthosis.

Although they can be found anywhere in the aerodigestive tract, there appears to be a predilection for areas where there is a junction of squamous and ciliary epithelium. This includes the limen vestibuli (junction of the nasal vestibule and the nasal cavity proper), nasopharyngeal surface of the soft palate, midzone of the laryngeal surface of the epiglottis, upper and lower margins of the ventricle, undersurface of the vocal folds, and the carina and bronchial spurs (9). Interestingly, virus can be detected in the normal mucosa adjacent to lesions. It is thought that this provides a reservoir for regeneration of new papillomata (Figure 1).

The typical course is of recurrent lesions requiring frequent debulking. However, every patient is different and treatment must be tailored to the individual. Some people require such frequent debulking that tracheotomy is necessary for airway protection. This unfortunately frequently leads to lesions around the tracheotomy site (in essence, an iatrogenic squamociliary junction), but traditional thinking has been that this predisposes to distal tracheal disease. A recent study of children, however, suggests that those who require tracheotomy have more aggressive disease and have distal disease prior to tracheotomy, and thus recommends that no child be subjected to a tenuous airway merely to avoid tracheotomy (21).

The natural history of the disease includes spontaneous remission. It is impossible to know to whom or when this will occur. The causes of remission are not known, and while the exact incidence is not known, it is thought that approximately one-third will remit by age forty. This makes clinical trials somewhat difficult inasmuch as it confounds the ability to tell who remitted due to treatment and who remitted due to the natural history of the illness.

Distal disease can develop and portends a poorer prognosis due to its inaccessibility. Clinically patients develop cavitary pulmonary lesions which can lead to atelectasis, chronic infection, post-obstructive pneumonia, and sepsis. It is thought distal disease is more common with HPV 11.

Rarely the lesions can undergo malignant degeneration which is almost uniformly fatal. One substantial risk factor is prior history of irradiation, a form of therapy no longer used to treat this disease.

\section{TREATMENT}

\section{Surgical}

The mainstay of therapy has been repeated debulking. The goal is to eradicate disease without damaging normal structures. No single modality has consistently been shown to be effective in eradication of RRP.

The current standard of care is surgical therapy with a goal of complete removal of papillomas and preservation of normal structures. In patients in whom anterior or posterior commissure disease or highly aggressive papillomas are present, the goal may be subtotal removal with clearing of the airway. It is advisable to "debulk" as much disease as possible while preserving normal morphological appearance and anatomy and preventing the complications of subglottic and glottic stenosis, web formation, and a diminished airway. The $\mathrm{CO}_{2}$ laser has been favored over cold instruments in the treatment of RRP involving the larynx, pharynx, upper trachea, and nasal and oral cavities (12). A recent survey of otolaryngologists showed that $92 \%$ favored the laser (12). Although the $\mathrm{CO}_{2}$ laser is the most commonly used laser for RRP in the larynx, the KTP, as well as the Argon laser, could also be used. Papillomas that have extended down the tracheo-bronchial tree often require use of the KTP laser coupled to a ventilating bronchoscope for removal. Occasionally, the ventilating resectoscope can also be used in these circumstances. Care must be taken with the laser to avoid disastrous complications such as airway fire. Care must be taken to protect the operating room personnel as papillomata have been demonstrated in the laser plume. Good suction of smoke and laser 
operating masks are usually sufficient. Eye protection must be used to avoid laser damage to the globe. The fractional concentration of oxygen in inspired gas (FIO2) that is delivered to the patient should be as close to a room-air mixture as possible. Ideally, the laser is not used until the oxygen in the mixture is between $26 \%$ and $30 \%$. In selected circumstances, it may be warranted to proceed with an FIO2 at or below 40\%. These precautions are taken to minimize the possibility of a laser-induced endotracheal tube fire. As an initial procedure, a microcup forceps is used for obtaining a biopsy specimen from the bulkiest portion of papilloma.

Microdebrider is a relatively new device used in the removal of papillomas is the powered by laryngeal shaver blade (Xomed Surgical Microdebrider). Advocates of this technique claim that the shaver is safer,more accurate, prevents thermal injury, and the post-procedure oedema that may be associated with the use of the laser is minimized as tissue injury resulting from the shaver technique is confined to the superficial mucosa only. FLINT (22) stated that his patients who have been previously treated with the laser have reported reduced postoperative pain and quicker recovery of voice since he adopted the shaver technique. Using the shaver blade with the aid of a rigid telescope with a video system and a Hollinger-style laryngoscope, lesions can be easily removed in the subglottic region and trachea. For treatment of the difficult-to-manage airway, the shaver isinvaluable as it may be used to debulk tissue in proximity or direct contact with the endotracheal tube. Patel and Mackenzie (23) assessed the value of the new device in five adult patients with recurrent respiratory papillomatosis who had previously undergone laser surgery. They reported that shaver excision of papillomas provided good clearance of disease, easy collection of pathological samples, and a potentially safer and faster alternative to laser excision.

Management of the airway is controversial. In the apnea technique the patient is intubated and administered $100 \%$ oxygen for a period of time. The tube is then removed for a period of time while the surgeon works. The patient is then reintubated and reoxygenated. This may be advantageous in pediatric airways in which there is not much room to work around a tube. Other methods include use of a laser-safe tube and spontaneous ventilation. Another common method is jet ventilation. Although this is generally felt to be safe, there is concern that this method may lead to distal inoculation of the virus. In patients with an existing tracheotomy, a metal tracheotomy tube can be placed to allow laser surgery to be carried out safely. A recent survey of otolaryngologists found the percent who favored the various techniques as follows: laser-safe tube $46 \%$, jet ventilation $25 \%$, apneic $16 \%$, and spontaneous $12 \%$ (12).

\section{ADJUVANT}

Although surgical management remains the mainstay therapy for RRP, ultimately, as many a $10 \%$ of patients with the disease require some form of adjuvant therapy. The most widely adopted criteria for initiating adjuvant therapy are a surgery requirement of more than four procedures per year, distal multisite spread of disease, and/or rapid regrowth of papilloma disease with airway compromise.

Newer therapies which have been tested include alfa-interferon, indole-3-carbinol, acyclovir, retinoic acid, ribavirin, methotrexate, cidofovir, and photodynamic therapy. The most commonly recommended adjuvant therapy is interferon (12).

Interferon has been used in treating recurrent respiratory papillomatosis in the United States since the early 1980s. The mechanism of action of interferon is complex. It has an antiproliferative action slowing target cell growth by depleting essential metabolites,thus increasing the length of the multiplication cycle.

It is a product of human leukocytes, which has been shown to reduce the growth rate at which the papillomata grow, although Healy demonstrated that the initial benefit seen at six months was gone by one year (24). Although interferon has no direct anti-viral action, it does reduce the translation of viral proteins by interfering with normal host cell translation mechanisms and induce synthesis of intracellular enzymes that act to control viral growth (6). Interferon decreases the growth of papillomas and increases the time interval between surgical procedures. Interferon induces complete resolution of clinical disease in approximately $30 \%$ to $50 \%$ of patients and partial resolution in $20 \%$ to $42 \%(25,26,27)$.

Current standard of care includes therapy for patients requiring surgery greater than four times per year (12). The dose is increased to a target of $3 \mathrm{MU} / \mathrm{m} 2$ body surface areas. It is continued for at least six months. Its side effects include flu-like symptoms, elevation of hepatic enzymes, renal insufficiency, anorexia, seizures, GI distress, and transient numbness (10). There is some suggestion that neutralizing antibodies may blunt its beneficial effect and that this may vary by brand (28).

Indole-3-carbinol is a naturally-occurring product of cruciferous vegetables which affects estrogen metabolism, shifting production to anti-proliferative estrogens. Only $25 \%$ of mice who were injected with papillomata and then fed with it developed disease as compared to $100 \%$ of controls (29). As compared with interferon some patients have a much more pronounced response than do others. 
A recent phase I trial showed a third of patients undergoing remission, a third slowing their rate of growth, and a third with no response (30). Adult's dosage is $200-400 \mathrm{mg}$ while 100-200 mg for children weighing less than $25 \mathrm{~kg}$ (10). It is well-tolerated.

Acylovir is a nucleoside analog that inhibits thymidine kinase, which is present in Herpesviruses but not HPV. A recent study has shown that some adults with RRP have molecular evidence of co-infection with other viruses, particularly HSV. It is felt that acyclovir acts to decrease disease by treating HSV which may potentiate HPV. However, HSV was not found in papillomata of children in one study $(31,32)$.

Retinoic acid is a Vitamin A derivative which has been shown to modulate epithelial differentiation. It is used clinically in a variety of different settings, but its use in RRP is still limited. Side effects include dry skin and chelitis.

Photodynamic therapy involves the administration of a photosensitizing agent, dihematoporphyrin, which is concentrated in rapidly growing tissues. Following administration of this agent, the lesions are then excised with a tunable argon pump dye laser which preferentially destroys the tissues which concentrated the dye. The main side effect is photosensitivity which lasts weeks to months, and has sometimes led to hospitalizations for cutaneous burns.

Ribavirin is also a nucleoside analog which has been shown to be useful in respiratory syncitial virus.

Methotrexate inhibits DNA synthesis and repair by affecting folate metabolism. It has been used with some success in some patients.

Cidofovir inhibits DNA polymerase and has been used successfully in AIDS-related infections. Investigation is currently underway and has been complicated by the fact that this drug may be carcinogenic.

\section{CONCLUSION}

Recurrent respiratory Papillomatosis is a frustrating, capricious disease with the potential for morbid consequences because of its involvement of the airway and the risk of malignant degeneration. Recurrent respiratory papillomatosis is a disease, which, although relatively uncommon, causes a substantial human and financial cost. Although the aetiological role of human papilloma virus has been well established, much remains to be understood regarding the precise mechanism of viral transmission, and the risk of disease expression in infants delivered to mothers with cervical human papilloma virus infection. The natural history of this disease is diverse. Although some patients enjoy an early spontaneous remission, some suffer from frequent and inexorable recurrences over many decades,occasionally suffering the catastrophic complication of malignant transformation. Unfortunately, there are as yet no clear prognostic indicators and this is certainly one area needing further investigation. Howerever, this article threw more lights in the current areas of surgical and adjuvant therapies.

\section{REFERENCE}

1. Ullmann EV. On the aetiology of the laryngeal papilloma. Acta Oto-Laryngologica. 1923, 5:317.

2. Hajek EF. Contribution to the etiology of laryngeal papilloma in children. Jour of Laryngol and Otol. 1956, 70:166.

3. Boyle WF, Riggs JF, Oshiro LS et al. Electron microscopic identification of papova virus in laryngeal papilloma. Laryngoscope. 1973, 83:1102.

4. Quick CA, Watts SL, Krzyzek RA et al. Relationship between condylomata and laryngeal papillomata. Ann of Otol, Rhinol \& Laryngol. 1980, 89:467.

5. Bennet RS, Powell KR. Human Papillomaviruses: Associations Between Laryngeal Papillomas and Genital Warts. Pediatr Infect Dis Jour. 1987, 6:22-32.

6. Strong SM, Jako GJ. Laser surgery in the larynx: clinical early experience with continuous CO2 laser. Ann of Otol, Rhinol \& Laryngol. 1972, 81:791-8.

7. Murray LN, Miller RH. Recurrent respiratory papillomatosis. Jour of the Louisiana St Med Socie. 1998, 150(10):456-9.

8. Doyle DJ, Gianoli GJ, Espinola T, Miller RH. Recurrent respiratory papillomatosis: juvenile versus adult forms. Laryngoscope. 1994, 104:523-527.

9. Derkay CS. Recurrent respiratory papillomatosis. Laryngoscope. 2001, 111:57- 69.

10. Bauman NM, Smith RJ. Recurrent respiratory papillomatosis. Pediatr Clin of North Am.1996, 43(6):1385401.

11. Deskin RW. Laser laryngoscopy for papilloma removal. In Bailey BJ et al. Atl of Head \& Neck Surg - Otolaryngol. Lippincott-Raven, 1998. 
12. Derkay CS. Task force on recurrent respiratory papillomatosis. Arch of Otolaryngol Head and Neck Surg. 1995, 121:1386-91.

13. Kashima HK, Mounts $\mathrm{P}$, Shah K. Recurrent respiratory papillomatosis. Obst and Gyne Clin of North Am. 1996, 23(3):699-706.

14. Hajek EF. Contribution to the etiology of laryngeal papilloma in children. Jourl of Laryngol and Otol. 1956, 70: 16.

15. Kashima H, Shah F, Lyles A, et al. Factors in juvenileonsetand adult onset recurrent respiratory papillomas. Laryngoscope. 1992, 102:9-13.

16. Bauman NM, Smith RJ. Recurrent respiratory papillomatosis. Pediatr Clin North Am. 1996, 43:13851401.

17. Shykhon M, Kuo M, Pearman,K. Recurrent respiratory papillomatosis. Clin Otolaryngol. 2002, 27:237-243.

18. Kosko JR, Derkay CS. Role of cesarean section in prevention of recurrent respiratory papillomatosis - is there one? Int Jour of Pediatr Otorhinolaryngol. 1996, 35(1):31-8.

19. Shah K, Kashima HK, Polk BF, et al. Rarity of cesarean delivery in cases of juvenile-onset respiratory papillomatosis. Obst and Gyne. 1986, 68:795.

20. Shapiro AM, Rimell FL, Pou A, etal. Tracheotomy in children with juvenile-onset recurrent respiratory papillomatosis: the children's hospital of Pittsburgh experience. Ann of Otol, Rhinol \& Laryngol. 1996, 105:1-5.

21. Flint P. Powered laryngeal surgery using the angle-tip rad airway blade. At website http://www.xomed.com/ Surgical-Techniques/surgTechnical. Accessed on 9/7/2001

22. Patel RS, Mackenie K. Powered laryngeal shavers and laryngeal papillomatosis: a preliminary report. Clin. Otolaryngol. 2000, 25:358-360.

23. Healy GB, Gelber RD, Trowbridge AL, et al. Treatment of recurrent respiratory papillomatosis with human leukocyte interferon. N. Engl. J. Med. 1988, 319:401-7.

24. Healy GB, Gelber RD, Trowbridge AL et al.Treatment of recurrent respiratory papillomatosis with human leukocyte interferon. N Engl J Med. 1988, 319:401-407.

25. Leventhal B, Dedo H, Gardiner L. et al.Interferon alfan1 (Wellferon) in juvenile onset recurrent respiratory papillomatosis: results of a randomized study in twelve collaborative institutions. Laryngoscope. 1998, 334-340.

26. Lunquist PG, Haglund S, Carlsoo B. et al.Interferon therapy in juvenile laryngeal papillomatosis. Otolaryngol.Head Neck Surg. 1984, 92:386-391.

27. Green M. RRP Website. At www.rrpwebsite.org. Accessed 2/28/99.

28.Newfield L, Goldsmith A, Bradlow HL, et al. Estrogen metabolism and human papillomavirus-induced tumors of the larynx: Chemo-prophylaxis with Indole-3-Carbinol. Anticancer Research. 1993, 13:337.

29. Rosen CA, Woodson GE, Thompson JW, etal. Preliminary results of the use of indole-3-carbinol for recurrent respiratory papillomatosis. Otolaryngol - Head \& Neck Surg. 1998, 118(6):810-5.

30. Pou AM, Rimell FL, Jordan JA, et al. Adult respiratory papillomatosis: Human papilloma virus (HPV) type and viral coinfections as predictors of prognosis. Ann of Otol, Rhinol \& Laryngol. 1995, 104:758.

31. Rimell FL, Shoemaker DL, Pou AM, et al. Pediatric respiratory papillomatosis: Prognostic roel of viral typing and cofactors. Laryngoscope. 1997, 107:915-8. 